\title{
What Is Driving Gender Equality in Secondary Education? Evidence from 57 Developing Countries, 1970-2010
}

\author{
Gudrun Østby, Henrik Urdal, and Ida Rudolfsen \\ Peace Research Institute Oslo (PRIO), P.O. Box 9229 Grønland, 0134 Oslo, Norway \\ Correspondence should be addressed to Gudrun Østby; gudrun@prio.org
}

Received 2 August 2016; Accepted 31 October 2016

Academic Editor: Jose C. Nunez

Copyright ( 2016 Gudrun Østby et al. This is an open access article distributed under the Creative Commons Attribution License, which permits unrestricted use, distribution, and reproduction in any medium, provided the original work is properly cited.

\begin{abstract}
Despite global efforts to expand educational opportunities for women, gender inequalities persist in many developing countries. Addressing the root causes of gender inequalities in secondary education we ask whether such disparities persist because of low state capacity or low willingness. Based on gender- and age-specific educational attainment data for 57 developing countries in 1970-2010, our analysis indicates that willingness factors are central to understanding gender equality in education: ethnically heterogeneous countries and countries where Islam is the primary religion experience lower levels of equality. However, key capacity factors like a country's income level are unrelated to gender differences in education.
\end{abstract}

\section{Introduction}

Vast education inequalities between women and men persist in many parts of the world. This article addresses whether these differences are purely a result of low state capacity to expand education opportunities for girls or whether countries that fail to provide equal education opportunities for girls simply are those that systematically discriminate women and are unwilling to address inequalities.

The 2012 World Development Report focused on gender and development and states explicitly that gender equality is a core development objective [1]. According to the report, gender equality enhances the productivity of the current generation and improves development outcomes for the next. Several studies have shown that educating girls is one of the most efficient ways to fight poverty and increase economic growth (e.g., $[2,3])$. Economists and international development agencies believe that educating girls is beneficial not only due to their own improved vocational opportunities, living conditions, and social status, but also because it promotes economic growth and social development of the entire nation, not least due to the positive influence of educated mothers on the human capital and health of their children (e.g., [4]).
In 2000, the world's governments adopted the six Education for All (EFA) goals to meet the needs of all children, youth, and adults by 2015, including Goal 5: "eliminating gender disparities in primary and secondary education by 2005 and achieving gender equality in education by 2015 , with a focus on ensuring girls' full and equal access to and achievement in basic education of good quality." (See http://www.unesco.org/new/en/education/themes/leadingthe-international-agenda/education-for-all/efa-goals/.) Millennium Development Goal (MDG) Number 3 was to eliminate gender disparities in primary and secondary education by 2005 and at all levels of education by 2015 . This goal was not met and is echoed in the new Sustainable Development Goals (SDGs), which also includes the quality aspect of equal education opportunities (cf. SDG Target 4.1), which reads as follows: "by 2030, ensure that all girls and boys complete free, equitable, and quality primary and secondary education leading to relevant and effective learning outcomes" (see http://en.unesco.org/gem-report/sdg-goal-4).

Despite recent global educational improvements gender inequalities persist in education, particularly in developing countries. (We focus here on gender parity in education in developing countries, as patterns of gender inequalities in developing countries are quite different than those in 
most industrialized societies [5].) Systematic educational inequality between boys and girls is now much wider at the level of secondary education. In many countries the introduction of free primary education led to a significant increase in enrollment. This in particular enabled access for girls, poor people, and other marginalized groups. However, it also led to lower quality due to the limited resources to meet the demand. Even where free secondary education has been introduced, the lower enrollment and retention of girls in secondary education persist in most low-income countries, indicating that the lasting impact of low quality and discrimination during primary education is working as a barrier to transition ([6]: 7; [7]). Hence, the focus in this article is on secondary education. That is, we are interested in comparing the shares of boys and girls who have at least some secondary education (i.e., lower secondary education and above).

In this article, we address the root causes of gender inequalities in secondary education and thereby assess the conditions under which countries may be able to achieve gender parity in education. We identify two broad sets of factors that have been associated with the level of educational gender parity in the literature and define them as primarily reflecting state capacity or state willingness. These include factors related to economic development, demography, culture, political institutions, and armed conflict. We understand state capacity to be the ability of a state government to implement its preferred policies and willingness to be the factors that shape these preferences. In a panel study of 57 developing countries for the period 1970-2010, we test two propositions using new data on gender and age in secondary education.

The remainder of the article is structured as follows. In Section 2 we present some trends with regard to educational attainment and gender parity and elaborate on the background for a set of hypotheses regarding the various potential drivers of educational gender equality. Section 3 presents the data and research design. In Section 4 we present our empirical results, and Section 5 concludes.

\section{Gender Parity in Education}

As demonstrated by Figure 1, there has been a steady progress over time in women's and girls' access to secondary education across all world regions, with the sharpest increase happening in countries in the Middle East and North Africa (MENA). Also, the gender gap has been reduced over time. However, there are still significant variations within the regions. (See Appendix, Table 1 and Figures 2 and 3 for details.) In 2005, 82 out of 120 countries (i.e., 68 percent) with data available had achieved relative gender equality in secondary education, referred to in this article as "gender parity," with a Gender Parity Index (GPI) of 0.95 and above. (The index measures the number of women aged 15-24 with at least completed secondary education divided by the number of men at the same educational level aged 15-24. Figures above 1.00 indicate that a greater share of girls than boys have secondary education. Note that gender parity may occur even at low overall levels of education.) For developing countries, the corresponding rate was only 41 percent ( 25 out of 61 countries).

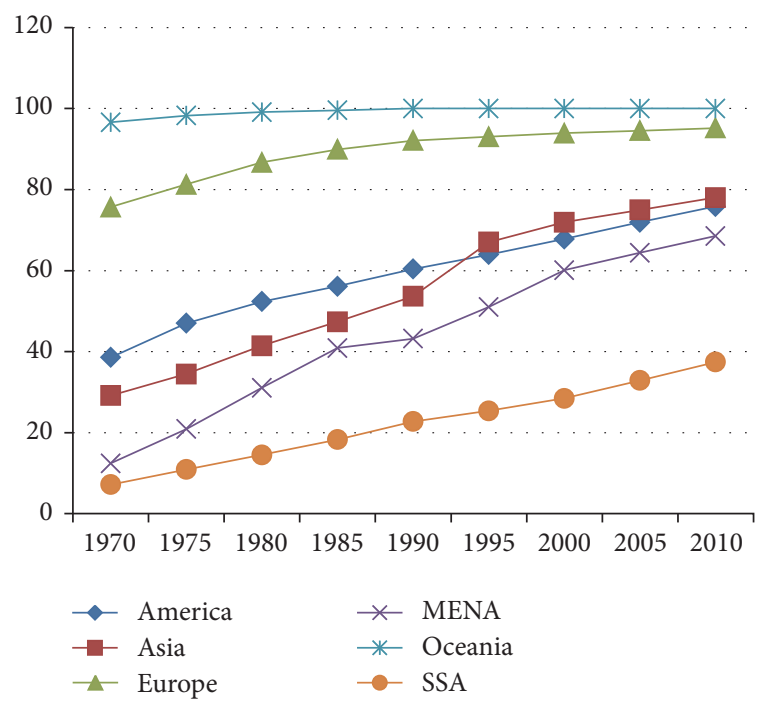

FIgURE 1: Share of females (15-24) with at least some secondary education (lower secondary education and above), by region. (See Appendix, Figure 5 for a corresponding figure that pertains to share of females (15-24) with at least some primary education, by region.).

TABLE 1: Gender parity in secondary education by region, 2010.

\begin{tabular}{|c|c|c|c|c|c|}
\hline Region & Obs & Mean & Std. Dev. & Min & Max \\
\hline America & 10 & 1.069 & 0.138 & $\begin{array}{c}0.893 \\
\text { (Haiti) }\end{array}$ & $\begin{array}{c}1.339 \\
\text { (Honduras) }\end{array}$ \\
\hline Asia & 16 & 0.934 & 0.161 & $\begin{array}{c}0.604 \\
\text { (Nepal) }\end{array}$ & $\begin{array}{c}1.114 \\
\text { (Mongolia) }\end{array}$ \\
\hline Europe & 4 & 1.009 & 0.003 & $\begin{array}{c}1.005 \\
\text { (Bulgaria) }\end{array}$ & $\begin{array}{c}1.013 \\
\text { (Armenia) }\end{array}$ \\
\hline MENA & 6 & 0.935 & 0.152 & $\begin{array}{c}0.804 \\
\text { (Morocco) }\end{array}$ & $\begin{array}{c}1.212 \\
\text { (Syria) }\end{array}$ \\
\hline SSA & 25 & 0.734 & 0.196 & $\begin{array}{c}0.364 \\
\text { (Chad) }\end{array}$ & $\begin{array}{c}1.111 \\
\text { (Madagascar) }\end{array}$ \\
\hline
\end{tabular}

On average at the global level $31 \%$ of the countries with data are projected not to have reached gender parity in primary education. Progress is slower when it comes to secondary education, with $52 \%$ projected still not to be at gender parity in 2015.

In the following we develop a framework for understanding and capturing the magnitude of education gender disparities. We identify two broad categories of factors assumed to determine low female education levels and thus low gender parity in secondary education. These are broadly defined as factors affecting states' capacity to address education inequalities, versus their willingness. Arguably, there can be instances where countries might have the capacity to improve gender gap but are unwilling to do so for political or cultural reasons, or where the state is willing but unable to increase female participation in education. However, the categories of capacity and willingness should be understood as conceptual tools to facilitate a discussion about the fact that governments face both real obstacles but also policy choices in addressing gender inequality in education. Also, rather than providing 


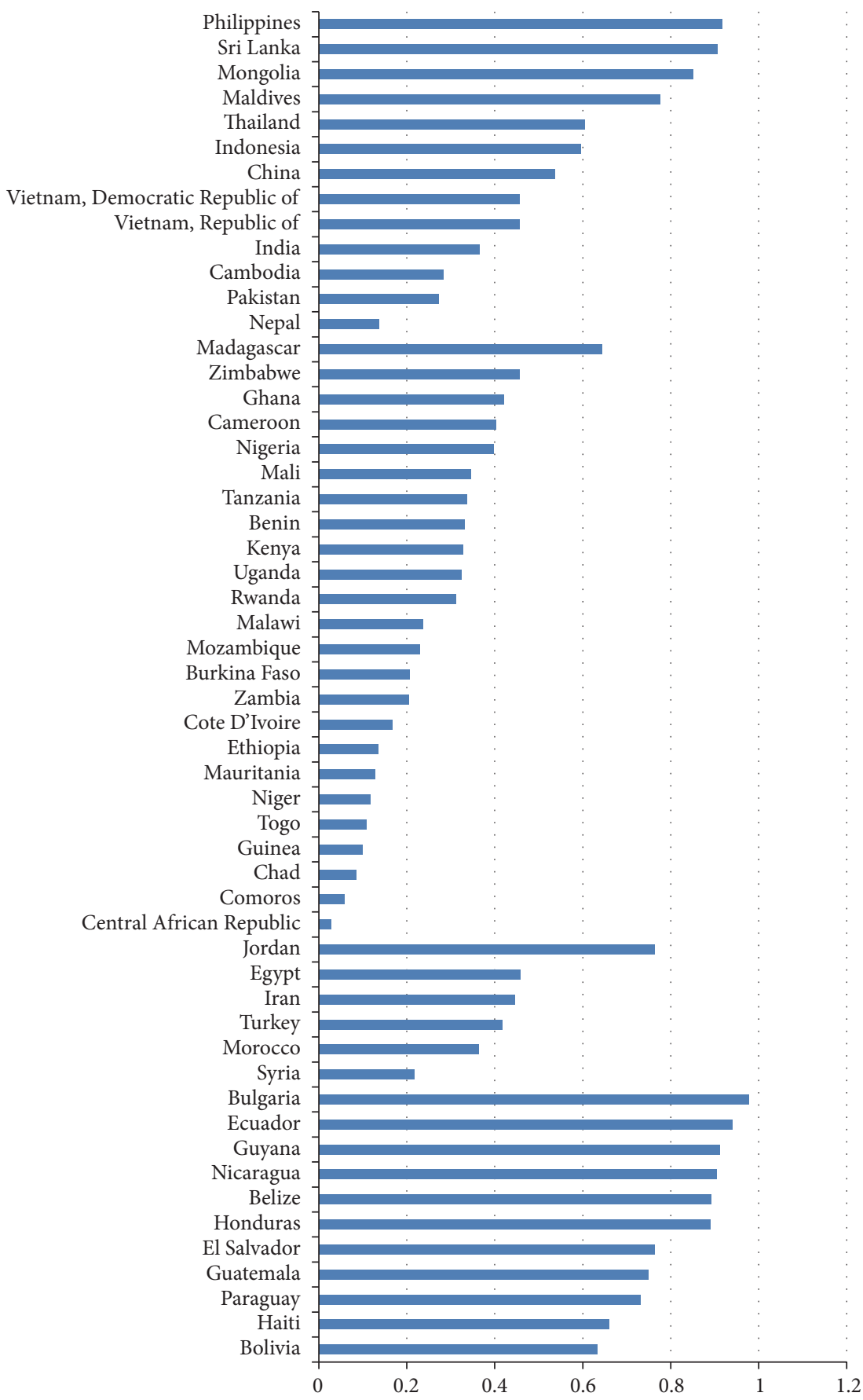

FIGURE 2: Developing countries: gender parity in secondary education by country, 1970.

clear-cut categories, distinctions between aspects of capacity and willingness can be blurred, and in particular when it comes to measurement. This will be further discussed below.

\subsection{Is Gender Inequality a Result of Low Capacity? Capacity is} understood as the ability of a state government to carry out its preferred policies. Low capacity may arise as a result of either low bureaucratic quality, limited financial resources, or high costs, or the combination of the three, making it difficult for states to achieve desired policy outcomes. According to
Müller [8], gender equality in education is more likely to be achieved if the state takes on a leading role to close the gender gap. However, although some states may be willing to introduce an enabling environment for female education, the bureaucratic quality of governments to do so can be limited, especially in developing countries. In low-income contexts, limited financial resources reduce the capacity to fund public services, and factors like large youth cohorts or dispersed populations may increase costs considerably, as may armed conflict. Conversely, external development aid may 


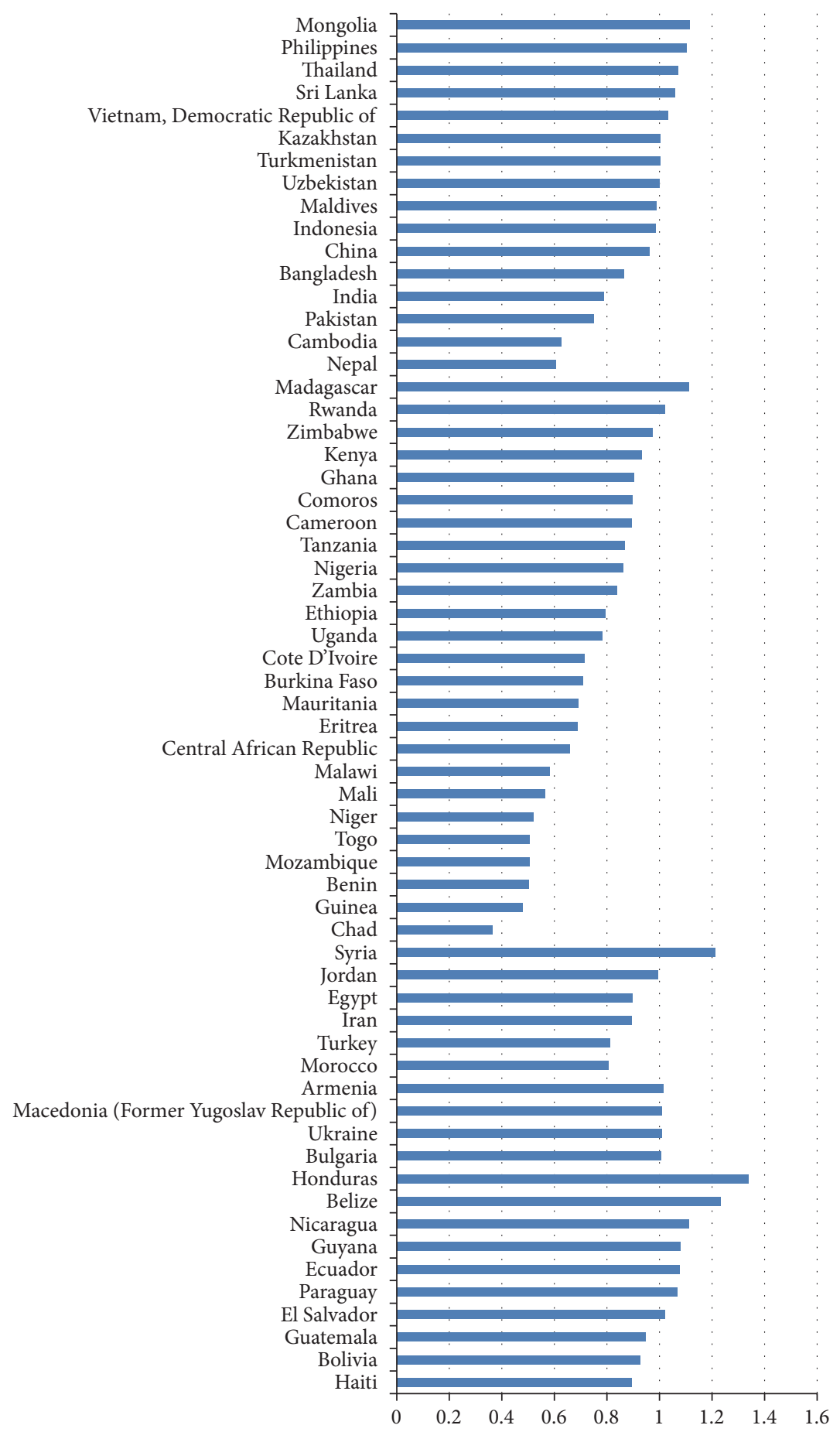

FIGURE 3: Developing countries: gender parity in secondary education by country, 2010.

contribute to offsetting low capacity. As families in many poor contexts depend on their offspring for economic security, and men are still the primary breadwinners, our assumption is that, at lower levels of capacity, boys will be prioritized.

2.1.1. Economic Development. Historical data reveal a positive correlation between gender parity in education and economic development. The general conclusion that emerges from the literature is that economic development and gender equality are mutually reinforcing. While higher female education is generally acknowledged to raise national income, and higher income in turn leads to greater gender equality in education and in society at large (e.g., $[3,10,11])$, the relative education status of women in many developing countries is still low [3].

Why should poor economic development halt the progression towards greater gender parity in education? In 
general, the level of economic development should affect both the education system (the supply of schooling) and the returns to education and the ability and willingness of parents to send their children, including their daughters, to school (the demand for schooling) [12].

On the one hand, in poor countries where the number of children exceeds the capacity of schools, an increase of public education expenditures can expand the capacity of schools by providing more classrooms and teachers. With added capacity in schools, more children will be able to enroll in education. And if it is the case that majority of the boys in the population are already enrolled in schools, then it is likely that the majority of the new incoming students will be girls. This will in turn increase the female-male student ratio and hence increase gender parity [11]. On the other hand, female schooling may be particularly sensitive to the costs associated with formal education. In other words, poverty can hinder girls' education by affecting individual parents' decisions as well as the government's educational efforts. For example, the opportunity cost of education including income from child labor tend to be higher for girls since they are more often expected to do housework, take care of younger siblings, and/or work in agriculture [10]. In a case-study from Kajiado in Kenya, Warrington and Kiragu [13] found that, due to the tradition of early marriage, education of girls was often perceived as meaningless. Hence, when family income was short the already limited resources were rather spent on boys' education.

In addition, underdevelopment, poor infrastructure, and low government spending on education typically correlate with poor quality education. In fact, various case studies (e.g., King and van der Walle [14] on Laos and Lloyd et al. [15] on Egypt) have shown that compared with boys, girls are less likely to enroll in and more likely to drop out of poor quality schools. Poor quality schools include buildings with leaking roofs, broken walls, and dysfunctional sanitary facilities and schools whose teachers are absent and where teaching materials and textbooks never arrive $[16,17]$.

2.1.2. Aid. In accordance with the Sustainable Development Goals, donors have committed themselves to contribute to eliminate gender disparities in primary and secondary education, devoting an increasing share of aid to the education sector. However, there is a heated debate concerning whether or not foreign aid is effective in promoting economic development in the first place (see, e.g., [18-20]). Even recent surveys of the aid-growth literature have reached diametrically opposite conclusions. (Doucouliagos and Paldam [21] conclude that the aid effectiveness literature has failed to establish that aid works. In contrast, McGillivray et al. [22] stress that most research published since the late 1990s finds that aid indeed works.) Both camps have been criticized by Dreher et al. [67] for ignoring that different types of aid may not have the same economic effects on the recipient countries. For example, they found that education aid increases primary school enrollment while domestic spending does not (see also [23]).

But does aid per capita received by a nation improve gender equality in education? To our knowledge, this question has not been widely studied. We expect that aid can lower the cost of promoting secondary education for developing countries and hence increase the prospects that girls attend school. Also, whereas domestic expenditure on education is sometimes biased against the poor, donor strategies usually emphasize poor and disadvantaged target groups, in particular girls for whom school attendance is often lower than for boys ([24], see also [25] on gender targeting in international development aid). Norway's strategy for development cooperation, for example, emphasizes the importance of education reaching the most vulnerable groups, including girls in particular [6]. As such, while education aid increases the capacity of states, it also arguably reflects the willingness of the international community. Finally, international education aid often focuses on improving the physical learning environment and the quality of education, which may, as argued above, provide particular incentives for girls to attend school [26]. (One could of course argue that those nations that receive higher amounts of aid per capita have weaker government infrastructure and economies and are hence likely to have lower primary and secondary school attainment rates (see, e.g., [27]). However, since we focus on developing countries, we expect the effect of aid to be positive).

2.1.3. Urbanization. The world has recently crossed the point where more than half of the global population is urban, a trend driven by rapid rural to urban migration in developing countries [28]. Cities are centers of innovation, sociocultural melting pots, and drivers of social change [29]. There are several reasons to expect a positive influence of urbanization on gender parity in education.

Increased urbanization may lower the costs and increase the returns of education, both at the society and individual levels, consistent with our capacity argument. First, the high population density in urban areas provides for more efficient use of resources and lower per capita costs. Further, female teachers are more common in urban than in rural areas. Female teachers are role models who create a more secure environment for girls, and there is some evidence that they have proven effective in increasing enrollment and reducing dropouts [7]. Second, average incomes as well as returns to education are typically higher in urban areas assumed to reduce the educational gender bias against girls at the individual level [30]. From this follows that one should expect greater investment in human capital for both males and females, and hence less gender inequality as urbanization increases [31]. However, increased urbanization could also be associated with greater willingness as urban residents are generally less attuned to traditional gender roles dictated by customs and norms, making them more likely to send their girls to school $[11,32]$.

2.1.4. Large Youth Cohorts. High birth rates and decreasing infant mortality have produced a steadily increasing population of young people in many areas of the world. The resulting "youth bulges" may negatively impact gender equality in education. We argue that large youth cohorts represent potential capacity challenges in low-income countries, as the cost of expanding access to postprimary schooling in order 
to respond to large youth cohorts can be prohibitive (e.g., [33]). Large youth cohorts create pressures on educational resources that may force governments to first expand education to limited groups of the youth population. While such discrimination may take several forms, such as rural-urban, geographic, or ethnoreligious, it is also likely that, in countries with historical gender inequalities, education will be first expanded to boys, hence disfavoring girls. Our expectation is that, in countries that undergo age-structure transitions causing large youth cohorts, educational inequalities will be greater.

2.1.5. Armed Conflict. Concerning the literature on gender impacts of conflict most of the attention has focused on sexual and gender-based violence. However, a far wider set of gender issues must be considered to better understand the human consequences of armed conflict. Women and girls are likely to experience crises differently from men and boys and violent conflict can change the entire structure and dynamics of households [7, 34]. A growing literature notes the role of women and girls as combatants in civil conflicts $[35,36]$. However, we might expect most actors to target males rather than females, owing to fighting capabilities and traditional societal norms discouraging females from taking active part in military activities.

Along this line of reasoning, and as a direct result of the mobilization of young men for armed service, one should expect to see a negative effect on education specifically for young males. This is indeed what existing research has found. In a cross-national study of the 1980-1997 period Lai and Thyne ([37]: 286) estimate that conflict on average reduces enrolment in secondary education by two to three percent more for boys than for girls. Detailed household survey studies from Iraq [38] and Cote d'Ivoire [39] display similar relative disadvantages in education outcomes for boys. In Colombia, Angrist and Kugler [40] and Rodríguez and Sánchez [41] found that conflict had a negative effect on teenage boys' school enrollment as a result of boys' increased labor supply.

Arguably, these direct, gendered effects may be partly countered by a decline in the capacity of the state to provide public services during conflict, which could reduce any developments toward relative increases in girls' education. A similar effect could conceivably exist at the micro (family) level. During times of conflict, when resources are scarce and families focus mainly on survival, education discrimination in favor of boys could increase. In contexts of long-term crisis and state fragility, gender issues in education may look similar to issues in development contexts. Increased poverty may force parents into taking their daughters out of school to avoid direct costs. We are agnostic, however, as to whether capacity factors may be sufficiently important to outweigh the documented direct negative effects of conflict primarily affecting young male education.

In line with the above discussion we expect that factors assumed to affect the state's capacity to provide public services are associated with increased gender parity in education. This informs our first broad hypothesis:
(H1) A higher level of state capacity increases gender parity in education.

2.2. Is Gender Inequality a Result of Low Willingness? If education inequalities are not merely driven by capacity factors, we suggest that an alternative source of inequality is the lack of political willingness. While capacity factors are partially reflecting discrimination since we expect low capacity to lead to a relatively lower prioritization of education for girls relative to boys, willingness relates to factors that capture discriminatory practices towards girls that are not directly related to the ability to pay for their education. It should be emphasized, however, that the source of unwillingness does not have to come from the government itself. Rather, their policy decision to not effectively address gender inequalities in education could stem from popular opposition or unwillingness among influential groups in society. While this may arguably include dynamics that in reality limits a government's room for maneuver, we nevertheless find it analytically helpful to separate between factors that determine the policies and those that limit a government's ability to carry out that preferred policies. We address three factors that may affect willingness, ethnic fractionalization, the dominant religion of a country, and its level of democracy.

2.2.1. Ethnic Fractionalization. Greater ethnic diversity, or fractionalization, may affect the level of government investment in broad public service programs. In general, ethnic fractionalization is commonly associated with identity politics, patronage, and distribution conflicts, affecting the attachment of minorities to the states and reducing the ability to developing strong institutions in multiethnic states [42]. Ethnic fragmentation has previously been found to negatively affect health outcomes such as child mortality [43] and also represents a potential political barrier to broad public investment in education [10].

While systematic differences in education between ethnic and religious groups are well documented and acknowledged $[44,45]$, relatively little attention has been paid to the gender dimension of educationally disadvantaged ethnic minorities. The UNESCO Global Monitoring Report 2015 reports that the gender gap in education is often greater among ethnically disadvantaged groups ([45]: 97). Studying the association between girls' primary school attainment and degree of ethnic heterogeneity across 120 countries, Lewis and Lockheed [46] found that countries that are ethnically and linguistically heterogeneous have more difficulty in reaching universal primary education-and more difficulty bringing girls into school-than do more homogeneous countries at similar development levels. Similarly we assume that the higher likelihood that multiethnic states are unwilling to fund large, universal public service programs is likely to translate into slower progress towards gender equality in education.

2.2.2. Religion. Another culturally related hypothesis that features in the literature on educational gender inequality is the assumption that religion determines attitudes to education of girls and hence influences gender parity (see, e.g., [2, 3, 31]). 
One aspect in which Islam is usually perceived as having different values compared to those from the "Western culture" concerns the extent of respect for personal freedom, especially that of women [47]. Some studies report relatively higher levels of educational gender inequality in Muslim countries. For example, Norton and Tomal [31] in a study of 97 high- and low-income countries found that the proportion of Muslim and Hindu adherents in a country has a negative effect on female educational attainment. Similarly, Dollar and Gatti [3] found that high female educational attainment is associated with Protestantism, while low achievement is weakly associated with Islam and Hinduism. Forsythe et al. [48] explain such findings with the presence of patriarchal institutional arrangements that promote gender inequality (see also [49]). (It should be noted that looking at country averages could be misleading. Huntington's clash of civilizations thesis, for example, has been criticized by Fukuyama [50], who suggests that countries behave differently because they are at different stages of the modernization process (see also [51]). Holding that aggregate national data fail to provide enough information to test for the presence of different values between Islam and Western culture, Hajj and Panizza [47] argue that looking at individuals within a country is a better strategy. Using individual-level data from Lebanon they find no evidence for the hypothesis that Muslims discriminate against the education of girls. Rather, they find that both Muslim and Christian girls receive more education than their male counterparts and there is no significant (statistically or substantial) difference between the education gender gap of Muslims and Christians. Correspondingly, based on World Values Surveys in 97 countries, Seguino [52] find that religiosity is strongly linked to gender inequitable beliefs but that no one religion stands out as consistently more gender inequitable in its effects than all the others.)

2.2.3. Democracy. Democracy and equality are theoretically related. In general, democracy is expected to bring about more equal societies and hence promote gender equality [53]. As argued above, education of girls is conducive to economic development. In less democratic countries rulers who seek to sustain political power typically do not consider the development of an educated middle class to be in their interest and are generally less likely to heed popular demands by women for improved education equality [2]. In democracies, on the other hand, gender equality is promoted through an educated middle class; women can better express their views and interests and be empowered to take on positions of leadership. Also, democracy facilitates gender equality through mobilization of women and electoral accountability [32]. In democracies, it is easier for women to organize to express their views and interests; they have access to and can disseminate information; and they may lobby for improving their status through, for example, education. Finally, democracy increases women's bargaining power within the household [54]. This can in turn permit mothers to invest more in health and education of their children. Therefore, democratic institutions are considered to be conducive to gender equality. (While several studies have examined how democracy relates to such factors as economic growth, human development, world peace, and human rights (see, e.g., $[55,56]$ ), surprisingly little empirical research has addressed the relationship between democracy and gender equality, and the few existing studies have shown somewhat mixed results (see, e.g., $[2,32,57])$.)

To sum up, we expect that factors such as ethnic fractionalization, religion, and the level of democracy capture a state's willingness to promote gender parity in education. These proxies of state willingness to reduce educational inequalities are used to evaluate our second broad hypothesis:

(H2) A higher level of state willingness increases gender parity in education.

\section{Research Design}

The drivers of gender inequality in education are studied in a cross-national time-series study covering 57 developing countries in the 1970-2010 period. The education data is produced by the International Institute for Applied Systems Analysis (IIASA) and measures educational attainment for five-year age and sex intervals $[58,59]$. The units of observation are nonoverlapping country-five-year periods. We focus here on secondary education, the rationale being that a very high number of countries have either achieved or are about to achieve universal primary education. However, an equally central motivation for addressing secondary education is that, in order to qualify for employment in a modern economic sector, secondary or higher education is often a requirement. Hence, secondary education is assumed to significantly improve women's opportunities for paid labor. An added value compared to many prior studies of gender inequalities is that we are addressing educational attainment rather than enrollment. Attainment data measures the actual number of years a person has spent in school while education enrollment data typically measures the number of students enrolled at each level as a percentage of the cohorts at corresponding ages. Complete time series of public education enrollment data are not available for a high number of countries, in particular developing countries, and are likely subject to systematic reporting bias in many contexts. Enrollment data also does not account for no-shows and dropouts, which could vary significantly between countries and genders. Our assumption is that education attainment provides a significantly better measure by which to compare and study educational inequalities.

Our dependent variable, Gender parity, is operationalized as the share of women aged 15-24 with at least completed secondary education divided by the share of men in the same age group with at least completed secondary education. A value of 1 indicates gender parity, that is, an equal relative level of secondary education between the two sexes. A value below 1 indicates that relatively more men aged 1524 have attained secondary education compared to women of the same age, while a value above 1 indicates higher educational levels among women. This variable is similar to operationalizations of earlier studies of educational gender gaps (e.g., [2]). We thus allow the variable to vary above 1 , not making any assumptions about what a "natural" gender 
distribution in education could be. (For a significant proportion of our sample (35.5\%) female secondary education attainment is higher than the corresponding attainment for males, and given the setup of our model such countries will contribute to explaining greater "parity" beyond the point which technically is defined as parity ("1"). However, we believe that such setup is defendable given that higher female secondary education attainment is not a result of systematic bias against boys but may be due to biological causes (girls reaching mental maturity earlier than boys) [60] as well as possibly cultural practices (such as boys being attracted to "traditional" male occupations which have historically required lower formalized education) (see, e.g., [61]).)

We conduct the analysis using ordinary least squares (OLS), random effects, and fixed effect regression. As the dependent variable is continuous we use OLS regression and include random effects to account for group level variation and fixed effects to reduce the potential of omitted variable bias. Also, we cluster the observation by country to account for correlation between the error terms for unit observations over time. Clustered standard errors account for the assumption that all observations are independent of each other [62]. (Also, given that the dependent variable is quite persistent over time, we run models with gender parity as a lagged independent variable. Overall, the results are consistent, although the inclusion of a lagged dependent variable naturally explains a lot of the variation.)

The IIASA dataset contains information from 120 countries for the years 1970-2000 [58] with reliable projection data up until 2050 [59]. It covers 61 developing countries, including 25 countries with recent (since 2000) conflict experiences. The dataset consists of population estimates by age, gender, and highest educational attainment (4 categories: no schooling, some primary, completed lower secondary, and completed tertiary), and the categories are standardized and thus comparable across countries (unlike many studies of enrolment, which typically rely on variable national definitions of what is considered "secondary education"). The principle education variables analyzed include 15-24 year olds in the two higher attainment categories, that is, having at least completed lower secondary school.

Since we are focusing on education attainment in the 15-24 cohorts, which we expect to have completed their secondary education, we need to account for the fact that the education that these cohorts received were caused by factors in the past. This is not easily remedied since secondary education is attained over several years, typically during the ages 10-15. It is further complicated by the ten-year span of the cohorts of interest, and since parity in secondary education is conditioned on the level and gender distribution of primary education. In an attempt to capture these historical effects and to reduce the risk of reversed causality, we lead the education variables by ten years, so that the explanatory variables are matched with the education variables when the average age in the cohort in question was 10. (According to Hendrix [63], the best solution to deal with simultaneity is either to choose variables based solely on theory rather than empirical reasons or to use instrumental variable analysis. However, good instrumental variables are difficult to find, and another potential solution to reduce the threat of endogeneity is therefore to lead the dependent variable by ten years.) Hence, secondary education is explained by factors in the previous ten-year period (i.e., the level of education in 2000 is matched with explanatory variables observed in 1990). (This corresponds to a lagging of all control and explanatory variables.)

We follow the World Development Report [64] and code countries as developing if they are classified as lower income or lower middle income, resulting in 61 developing countries. (Belize, Comoros, Guyana, and the Maldives have been missing on several of the independent variables and are excluded from the analysis. This leaves 57 countries.)

Our variables capturing state capacity include bureaucratic quality, measuring the institutional strength and quality of the bureaucracy on a 4-point scale [65], development, measured as per capita income (GDP) (log-transformed) [66], education aid measured as averaged five-year aid commitments by all donors per capita [67] (as the sample from Dreher et al. [67] is only up to 2004, we also apply this value to 2005), level of urbanization defined as the proportion of the total population living in urban areas [28], youth cohort size defined as the proportion of youth aged 15-24 of the adult population (development, urbanization, and total population have missing values for some of the first and last country years, and these values have been extrapolated. Czechoslovakia, Hong Kong, Macau, Maldives, and the Republic of Vietnam lack information on these variables altogether and are not included in the analysis) [28], and internal armed conflict, a log-transformed measure of the aggregate number of casualties in conflict (battle-related deaths) in the preceding five-year period [68]. Measures of willingness include ethnic fractionalization from the Ethnic Power Relations dataset [69] and largest religion. Given the limitations imposed by our sample of developing countries, we separated countries into three groups, Catholic (used as reference category), Islamic, and Protestant or other majority religion. (We collapse these two categories as Protestantism has very few observations.) These terms were generated on the basis of La Porta et al.'s [70] data on the percentages of the major religions that make up a state. (Originally, these data are time-invariant (covering the 1980-2000 period), and we extrapolated the values to include our entire time-period, 1970-2010. We also include an alternative measure for religious belonging in Table 2, based on data from PEW [9].) The third willingness factor we use is level of democracy. We use Gates et al.'s [71] measure SIP (the "Scalar Index of Polities"). (The SIP democracy measure combines information on the regulation of executive recruitment and constraints from the POLITY data [72] with data on political participation from Vanhanen [73]. The conventional POLITY index has been criticized for relying of coding of "fractionalized systems," which could reflect political violence [74]. Using SIP allows us to both take into account the participation dimension of democracy, which is largely ignored in the more institutional focus of the POLITY data, and to avoid problems of factionalized competition. Despite our preference for SIP, we have also run our analyses with the more conventional POLITY data and the results remain largely the same, as shown in the Appendix, Table 3.) 
TABLE 2: Gender parity in secondary education attainment, developing countries: 1970-2010. Alternative measure of religion: PEW.

\begin{tabular}{|c|c|c|c|}
\hline & OLS & Random effects & Fixed effects \\
\hline \multirow{2}{*}{ Bureaucratic quality } & 0.019 & 0.004 & 0.002 \\
\hline & $(0.015)$ & $(0.008)$ & $(0.008)$ \\
\hline \multirow{2}{*}{ GDP per capita $(\ln )$} & 0.063 & 0.017 & -0.006 \\
\hline & $(0.029)^{* *}$ & $(0.033)$ & $(0.047)$ \\
\hline \multirow{2}{*}{ Average aid over 5 years } & 0.001 & 0.001 & 0.001 \\
\hline & $(0.0002)^{* * *}$ & $(0.0002)^{* * *}$ & $(0.0002)^{* *}$ \\
\hline \multirow{2}{*}{ Urbanization } & 0.676 & 1.005 & 1.076 \\
\hline & $(0.174)^{* * *}$ & $(0.132)^{* * *}$ & $(0.155)^{* * *}$ \\
\hline \multirow{2}{*}{ Youth cohort size } & 0.012 & 0.010 & 0.010 \\
\hline & $(0.004)^{* * *}$ & $(0.004)^{* * *}$ & $(0.005)^{*}$ \\
\hline \multirow{2}{*}{ Armed conflict intensity $(\ln )$} & 0.0002 & 0.001 & 0.001 \\
\hline & $(0.003)$ & $(0.002)$ & $(0.001)$ \\
\hline \multirow{2}{*}{ Ethnic fractionalization } & -0.263 & -0.229 & \\
\hline & $(0.066)^{* * *}$ & $(0.072)^{* * *}$ & \\
\hline \multicolumn{4}{|c|}{$\begin{array}{l}\text { Religious belonging (ref. cat: other } \\
\text { (other: Buddhism, Hinduism, Folk } \\
\text { religion, and unaffiliated [9].)) }\end{array}$} \\
\hline \multirow{2}{*}{ Christianity } & -0.081 & -0.086 & \\
\hline & $(0.074)$ & $(0.081)$ & \\
\hline \multirow{2}{*}{ Islam } & -0.233 & -0.207 & \\
\hline & $(0.079)^{* * *}$ & $(0.087)^{* *}$ & \\
\hline \multirow{2}{*}{ Democracy level } & 0.028 & -0.012 & -0.014 \\
\hline & $(0.062)$ & $(0.034)$ & $(0.033)$ \\
\hline \multirow{2}{*}{ Population } & -0.0001 & 0.00002 & 0.0002 \\
\hline & $(0.0001)$ & $(0.0001)$ & $(0.0002)$ \\
\hline \multirow{2}{*}{1975} & -0.011 & -0.008 & -0.006 \\
\hline & $(0.021)$ & $(0.024)$ & $(0.025)$ \\
\hline \multirow{2}{*}{1980} & -0.007 & -0.009 & -0.008 \\
\hline & $(0.020)$ & $(0.014)$ & $(0.013)$ \\
\hline \multirow{2}{*}{1985} & 0.014 & 0.008 & 0.007 \\
\hline & $(0.020)$ & $(0.014)$ & $(0.013)$ \\
\hline \multirow{2}{*}{1990} & 0.040 & 0.037 & 0.036 \\
\hline & $(0.019)^{* *}$ & $(0.013)^{* * *}$ & $(0.011)^{* * *}$ \\
\hline \multirow{2}{*}{1995} & 0.064 & 0.054 & 0.049 \\
\hline & $(0.019)^{* * *}$ & $(0.012)^{* * *}$ & $(0.012)^{* * *}$ \\
\hline \multirow{2}{*}{ Constant } & -0.158 & 0.145 & 0.041 \\
\hline & $(0.263)$ & $(0.253)$ & $(0.340)$ \\
\hline$R^{2}$ & 0.58 & & 0.47 \\
\hline$N$ & 401 & 401 & 401 \\
\hline
\end{tabular}

This measure ranges from 0 to 1 , where lower values indicate countries with more autocratic features such as the absence of party competition and the right to vote, while higher values are given to more democratic systems with universal suffrage and effective party competition. Finally, we control for total population [28] and include period dummies to account for the general improvement in educational attainment over time. Also, we expect endogeneity issues to be somewhat ameliorated with the usage of time dummies in the models, as they account for some of the effects gender parity in education have on state capacity and willingness.

\section{Results}

This section reports the results from the multivariate empirical evaluations of the factors associated with state capacity 
TABLE 3: Gender parity in secondary education attainment, developing countries: 1970-2010. Alternative measure of democracy: POLITY IV.

\begin{tabular}{|c|c|c|c|}
\hline & OLS & Random effects & Fixed effects \\
\hline \multirow{2}{*}{ Bureaucratic quality } & 0.024 & 0.005 & 0.003 \\
\hline & $(0.015)$ & $(0.008)$ & $(0.008)$ \\
\hline \multirow{2}{*}{ GDP per capita $(\ln )$} & 0.048 & 0.011 & -0.004 \\
\hline & $(0.040)$ & $(0.038)$ & $(0.048)$ \\
\hline \multirow{2}{*}{ Average aid over 5 years } & 0.001 & 0.001 & 0.001 \\
\hline & $(0.0002)^{* * *}$ & $(0.0002)^{* * *}$ & $(0.0002)^{* *}$ \\
\hline \multirow{2}{*}{ Urbanization } & 0.661 & 0.966 & 1.052 \\
\hline & $(0.207)^{* * *}$ & $(0.143)^{* * *}$ & $(0.157)^{* * *}$ \\
\hline \multirow{2}{*}{ Youth cohort size } & 0.011 & 0.010 & 0.010 \\
\hline & $(0.005)^{* *}$ & $(0.004)^{* * *}$ & $(0.005)^{*}$ \\
\hline \multirow{2}{*}{ Armed conflict intensity $(\ln )$} & -0.0004 & 0.001 & 0.001 \\
\hline & $(0.003)$ & $(0.002)$ & $(0.002)$ \\
\hline \multirow{2}{*}{ Ethnic fractionalization } & -0.256 & -0.225 & \\
\hline & $(0.073)^{* * *}$ & $(0.072)^{* * *}$ & \\
\hline \multicolumn{4}{|l|}{ Largest religion (ref. cat: Catholicism) } \\
\hline \multirow{2}{*}{ Protestantism or other } & -0.043 & -0.047 & \\
\hline & $(0.060)$ & $(0.055)$ & \\
\hline \multirow{2}{*}{ Islam } & -0.189 & -0.177 & \\
\hline & $(0.057)^{* * *}$ & $(0.052)^{* * *}$ & \\
\hline \multirow{2}{*}{ Polity } & 0.003 & 0.0004 & 0.0001 \\
\hline & $(0.003)$ & $(0.002)$ & $(0.002)$ \\
\hline \multirow{2}{*}{ Population } & -0.00002 & 0.0001 & 0.0002 \\
\hline & $(0.0001)$ & $(0.0001)$ & $(0.0002)$ \\
\hline \multirow{2}{*}{1975} & -0.009 & -0.007 & -0.005 \\
\hline & $(0.020)$ & $(0.024)$ & $(0.025)$ \\
\hline \multirow{2}{*}{1980} & 0.0001 & -0.007 & -0.007 \\
\hline & $(0.022)$ & $(0.015)$ & $(0.014)$ \\
\hline \multirow{2}{*}{1985} & 0.022 & 0.008 & 0.006 \\
\hline & $(0.023)$ & $(0.015)$ & $(0.013)$ \\
\hline \multirow{2}{*}{1990} & 0.047 & 0.039 & 0.036 \\
\hline & $(0.019)^{* *}$ & $(0.013)^{* * *}$ & $(0.011)^{* * *}$ \\
\hline \multirow{2}{*}{1995} & 0.064 & 0.052 & 0.046 \\
\hline & $(0.018)^{* * *}$ & $(0.011)^{* * *}$ & $(0.011)^{* * *}$ \\
\hline \multirow{2}{*}{ Constant } & -0.052 & 0.166 & 0.051 \\
\hline & $(0.353)$ & $(0.296)$ & $(0.342)$ \\
\hline$R^{2}$ & 0.57 & & 0.47 \\
\hline N (POLITY has missing observations on Cambodia in 1980 and 1985) & 399 & 399 & 399 \\
\hline
\end{tabular}

${ }^{*} p<0.1 ;{ }^{* *} p<0.05 ;{ }^{* * *} p<0.01$.

or willingness to promote educational gender parity. We present our main analysis in Model 1, Table 4. In the two subsequent models we introduce random and fixed effects, respectively. Broadly speaking, the models performed quite well in the sense that they discriminated between the different hypothesized relationships, despite that the division between state capacity and willingness is quite broad.

Results for the gender parity models in Table 4 reveal some interesting relationships, and the results are consistent between the models.

When it comes to bureaucratic quality, our most direct measure of state capacity, the effect on gender parity is insignificant in all three models. Thus, the results suggest that the level of bureaucratic quality explains little of the variation in gender equality in education. Among developing countries, the level of economic development, which actually varies significantly within this group, also appears not to impact the gender balance in education. The relationship is positive, but statistically insignificant. The results from these two capacity measures appear to indicate that developing countries with higher bureaucratic quality and mid-income economies are not investing relatively more in education for girls compared to institutionally weaker and lower-income countries. This could be considered the primary indication 
TABLE 4: Gender parity in secondary education attainment, developing countries: 1970-2010.

\begin{tabular}{|c|c|c|c|}
\hline & $\begin{array}{c}\text { Model } 1 \\
\text { OLS }\end{array}$ & $\begin{array}{c}\text { Model } 2 \\
\text { Random effects }\end{array}$ & $\begin{array}{c}\text { Model } 3 \\
\text { Fixed effects }\end{array}$ \\
\hline \multirow{2}{*}{ Bureaucratic quality } & 0.021 & 0.0039 & 0.0020 \\
\hline & $(0.015)$ & $(0.0078)$ & $(0.0076)$ \\
\hline \multirow{2}{*}{ GDP per capita $(\ln )$} & 0.048 & 0.0097 & -0.0033 \\
\hline & $(0.040)$ & $(0.036)$ & $(0.047)$ \\
\hline \multirow{2}{*}{ Average aid over 5 years } & 0.00078 & 0.00061 & 0.00052 \\
\hline & $(0.00017)^{* * *}$ & $(0.00017)^{* * *}$ & $(0.00020)^{* *}$ \\
\hline \multirow{2}{*}{ Urbanization } & 0.631 & 0.988 & 1.085 \\
\hline & $(0.215)^{* * *}$ & $(0.142)^{* * *}$ & $(0.153)^{* * *}$ \\
\hline \multirow{2}{*}{ Youth cohort size } & 0.010 & 0.011 & 0.011 \\
\hline & $(0.0050)^{* *}$ & $(0.0039)^{* * *}$ & $(0.0054)^{* *}$ \\
\hline \multirow{2}{*}{ Armed conflict intensity $(\ln )$} & -0.00038 & 0.0012 & 0.0012 \\
\hline & $(0.0026)$ & $(0.0015)$ & $(0.0015)$ \\
\hline \multirow{2}{*}{ Ethnic fractionalization } & -0.271 & -0.241 & \\
\hline & $(0.072)^{* * *}$ & $(0.073)^{* * *}$ & \\
\hline \multicolumn{4}{|c|}{ Largest religion (ref: Catholicism) } \\
\hline \multirow{2}{*}{ Protestantism or other } & -0.054 & -0.051 & \\
\hline & $(0.059)$ & $(0.054)$ & \\
\hline \multirow{2}{*}{ Islam } & -0.188 & -0.177 & \\
\hline & $(0.057)^{* * *}$ & $(0.051)^{* * *}$ & \\
\hline \multirow{2}{*}{ Democracy level } & 0.071 & -0.0032 & -0.012 \\
\hline & $(0.072)$ & $(0.035)$ & $(0.033)$ \\
\hline \multirow{2}{*}{ Population } & -0.000012 & 0.000093 & 0.00025 \\
\hline & $(0.000082)$ & $(0.000079)$ & $(0.00016)$ \\
\hline \multirow{2}{*}{1975} & -0.0079 & -0.0087 & -0.0077 \\
\hline & $(0.020)$ & $(0.024)$ & $(0.025)$ \\
\hline \multirow{2}{*}{1980} & -0.00080 & -0.0089 & -0.010 \\
\hline & $(0.021)$ & $(0.014)$ & $(0.013)$ \\
\hline \multirow{2}{*}{1985} & 0.020 & 0.0059 & 0.0031 \\
\hline & $(0.023)$ & $(0.015)$ & $(0.013)$ \\
\hline \multirow{2}{*}{1990} & 0.048 & 0.038 & 0.035 \\
\hline & $(0.019)^{* *}$ & $(0.013)^{* * *}$ & $(0.011)^{* * *}$ \\
\hline \multirow{2}{*}{1995} & 0.065 & 0.054 & 0.048 \\
\hline & $(0.018)^{* * *}$ & $(0.012)^{* * *}$ & $(0.011)^{* * *}$ \\
\hline \multirow{2}{*}{ Constant } & -0.051 & 0.144 & -0.0094 \\
\hline & $(0.360)$ & $(0.293)$ & $(0.344)$ \\
\hline$R^{2}$ & 0.57 & & 0.48 \\
\hline$N$ & 409 & 409 & 409 \\
\hline
\end{tabular}

that lack of political will is driving education inequality, rather than lack of bureaucratic and financial capabilities.

While overall income levels have no influence on gender equality in education, higher education aid disbursements do positively affect education parity, albeit the effect is moderate.

Figure 4 summarizes the substantial effects from Model 1 in the form of changes in expected value of gender parity of secondary education with associated 95 percent confidence intervals. For the sake of simplicity, the figure groups the variables according to the capacity and willingness distinction, although, as discussed in the theory section, some variables may pertain to both capacity and willingness. If we compare the countries in our sample which receive the least ear-marked education aid (5th percentile) with the ones that receive the most such aid (95th percentile), the score on gender parity increased by 0.11 units. When considered jointly with the noneffect of income on gender parity, it appears that the positive effect that we see of education aid on gender parity suggests that it is due to political conditions underlying external aid and not the mere availability of funds. The result for the urbanization variable has the expected sign and the effect is very strong. If we move from low (5th percentile) to 


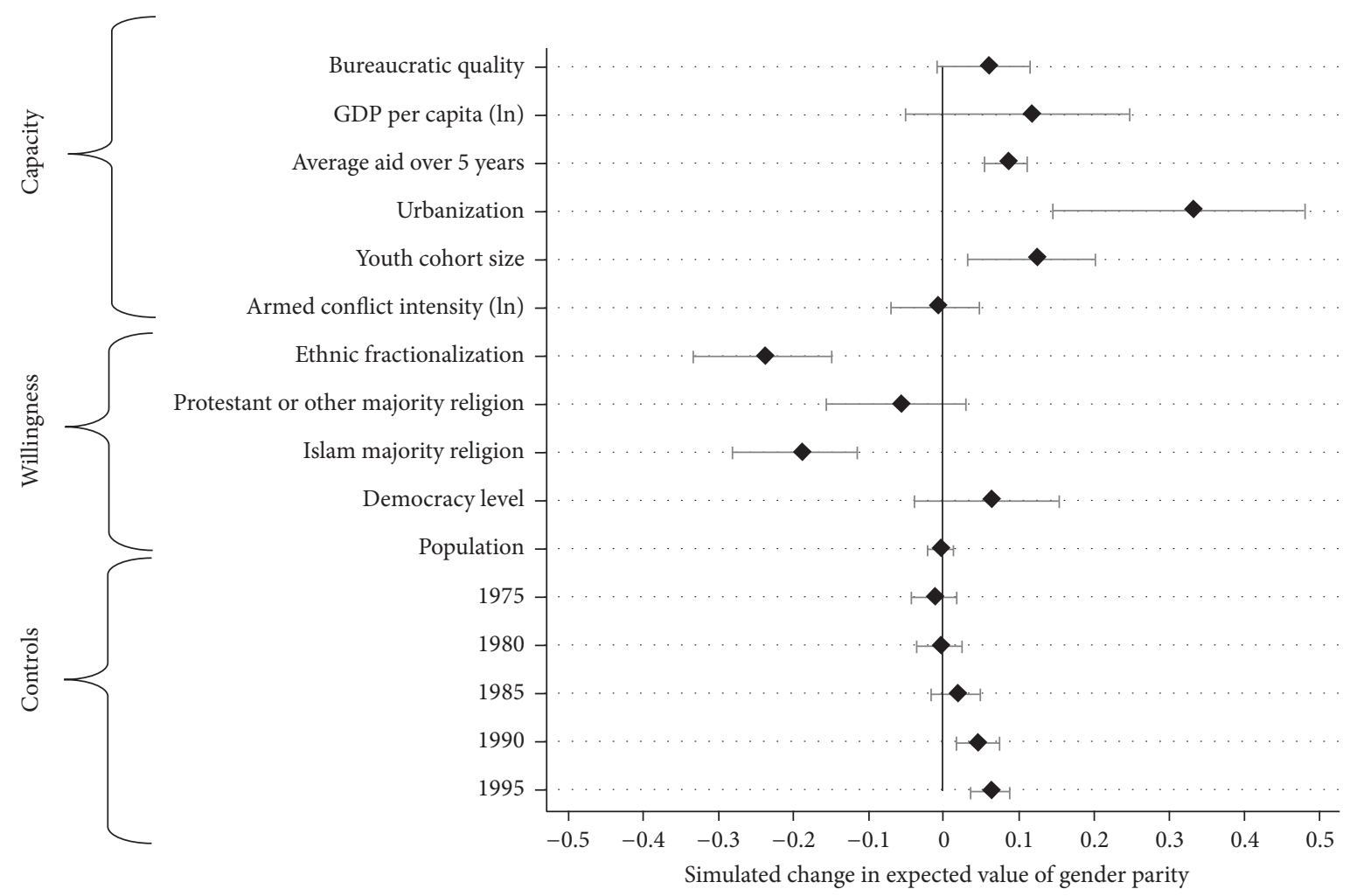

FIGURE 4: Simulated change in expected value of gender parity in secondary education attainment, developing countries: 1970-2010.

high urbanization levels (95th percentile), the gender parity score increases by 0.27 units. This finding that urbanized countries exhibit higher relative female secondary education levels indicates support for the capacity argument. Contrary to our expectation, large youth cohorts appear to have a positive effect on gender parity. Countries with the largest youth cohorts (95th percentile) score on average 0.12 points more on the gender parity scale compared to countries with the smallest youth cohorts (5th percentile), all other factors being equal. This result appears to indicate that when states are experiencing pressures for expanding education to meet the needs of burgeoning youth populations, rather than causing a political response that incentivizes the prioritization of males over females, the pressure for expanding education provides increased relative opportunities for women. Finally, armed conflict intensity, measured as battle-related deaths, has no impact on gender disparities in education. This could indicate that any negative impact of conflict on female education is offset by factors pulling in the opposite direction, such as greater female autonomy and greater education assistance directed towards refugees and internally displaced people, including displacement from rural areas to cities.

Moving to the variables that arguably capture some level of political willingness, we do find some of the strongest predictors of educational gender inequality. As expected, ethnically fractionalized countries have significantly lower secondary education levels among women than men. If we compare a country with low ethnic fractionalization (5th percentile) to high ethnic fractionalization (95th percentile), gender parity decreases by 0.17 points. Also, compared to countries where the majority religion is Catholicism, states with a Muslim majority religion score on average 0.21 points less on gender parity. However, as was shown in Figure 1, it is important to note that the Middle East and North Africa are the region where the rate of female secondary education has risen most rapidly during the period covered by the study. Surprisingly, democracy, our last willingness factor, appears to have no independent effect on gender parity for the countries in our sample. Yet, with the strong impact of the cultural terms, the results underscore the general conclusion that willingness is a crucial factor to ending gender inequality in education.

As regards the control for population size, it seems to have no significant impact on gender parity. However, as shown by the time dummies, gender parity in secondary education attainment is improving over time, presumably reflecting the increased attention paid to the importance of education among national governments and the international community at large. Further, the above results are largely robust to the introduction of fixed and random effects, respectively, as shown in Table 4.

Finally, the analysis could have benefited from more direct measures of state willingness by including measures such as share of women in Parliament, taken from Bjarnegård and Melander [53]. However, we have not included this in the main analysis. This is both because of widespread missingness, but also because it can be argued that the share of women in Parliament is a relatively poor measure of women's 
TABLE 5: Gender parity in secondary education attainment, developing countries: 1970-2010. Women in parliament included.

\begin{tabular}{|c|c|c|c|}
\hline & OLS & Random effects & Fixed effects \\
\hline \multirow{2}{*}{ Bureaucratic quality } & 0.034 & 0.017 & 0.014 \\
\hline & $(0.016)^{* *}$ & $(0.0071)^{* *}$ & $(0.0076)^{*}$ \\
\hline \multirow{2}{*}{ GDP per capita $(\ln )$} & 0.052 & 0.013 & 0.0055 \\
\hline & $(0.044)$ & $(0.039)$ & $(0.050)$ \\
\hline \multirow{2}{*}{ Average aid over 5 years } & 0.00063 & 0.00049 & 0.00037 \\
\hline & $(0.00014)^{* * *}$ & $(0.00014)^{* * *}$ & $(0.00016)^{* *}$ \\
\hline \multirow{2}{*}{ Urbanization } & 0.523 & 0.824 & 0.925 \\
\hline & $(0.225)^{* *}$ & $(0.146)^{* * *}$ & $(0.150)^{* * *}$ \\
\hline \multirow{2}{*}{ Youth cohort size } & 0.011 & 0.0086 & 0.0085 \\
\hline & $(0.0049)^{* *}$ & $(0.0034)^{* *}$ & $(0.0049)^{*}$ \\
\hline \multirow{2}{*}{ Armed conflict intensity $(\ln )$} & 0.0012 & 0.0017 & 0.0015 \\
\hline & $(0.0030)$ & $(0.0013)$ & $(0.0013)$ \\
\hline \multirow{2}{*}{ Ethnic fractionalization } & -0.259 & -0.232 & \\
\hline & $(0.079)^{* * *}$ & $(0.076)^{* * *}$ & \\
\hline \multicolumn{4}{|c|}{ Largest religion (ref. cat: Catholicism) } \\
\hline \multirow{2}{*}{ Protestantism or other } & -0.052 & -0.069 & \\
\hline & $(0.061)$ & $(0.055)$ & \\
\hline \multirow{2}{*}{ Islam } & -0.169 & -0.176 & \\
\hline & $(0.064)^{* *}$ & $(0.054)^{* * *}$ & \\
\hline \multirow{2}{*}{ Democracy level } & 0.100 & 0.052 & 0.046 \\
\hline & $(0.082)$ & $(0.031)^{*}$ & $(0.026)^{*}$ \\
\hline \multirow{2}{*}{ Women in parliament } & 0.0077 & 0.0046 & 0.0039 \\
\hline & $(0.0025)^{* * *}$ & $(0.0013)^{* * *}$ & $(0.0012)^{* * *}$ \\
\hline \multirow{2}{*}{ Population } & -0.000098 & 0.000049 & 0.00021 \\
\hline & $(0.0000845)$ & $(0.000067)$ & $(0.00012)^{*}$ \\
\hline \multirow{2}{*}{1975} & -0.0050 & 0.013 & 0.015 \\
\hline & $(0.036)$ & $(0.037)$ & $(0.039)$ \\
\hline \multirow{2}{*}{1980} & -0.010 & -0.0060 & -0.0058 \\
\hline & $(0.026)$ & $(0.014)$ & $(0.014)$ \\
\hline \multirow{2}{*}{1985} & 0.00033 & 0.0049 & 0.0041 \\
\hline & $(0.026)$ & $(0.014)$ & $(0.013)$ \\
\hline \multirow{2}{*}{1990} & 0.019 & 0.025 & 0.024 \\
\hline & $(0.019)$ & $(0.010)^{* *}$ & $(0.0094)^{* *}$ \\
\hline \multirow{2}{*}{1995} & 0.038 & 0.034 & 0.029 \\
\hline & $(0.017)^{* *}$ & $(0.0094)^{* * *}$ & $(0.010)^{* * *}$ \\
\hline \multirow{2}{*}{ Constant } & -0.121 & 0.211 & 0.027 \\
\hline & $(0.382)$ & $(0.307)$ & $(0.351)$ \\
\hline$R^{2}$ & 0.53 & & 0.49 \\
\hline$N$ & 320 & 320 & 320 \\
\hline
\end{tabular}

actual influence and status in society. However, robustness tests using this measure are included in the Appendix in Table 5.

\section{Conclusions}

Understanding what factors are associated with greater educational gender inequality, and what factors are present in countries that have achieved gender parity, is crucial for providing for a continued human and economic development.
The present article assesses the drivers of gender inequalities in secondary education in 57 developing countries during the period from 1970 through 2010. To our knowledge, this is the first cross-national study that systematically analyses a wide range of obstacles to and drivers of educational gender parity in secondary education over time.

Our findings broadly suggest that where gender inequality in education exists, this is primarily due to state willingness and not to capacity factors. While capacity factors may matter in some specific contexts, a country's bureaucratic 
TABLE 6: Descriptive statistics, developing countries, 1970-2010.

\begin{tabular}{|c|c|c|c|c|c|}
\hline Variable & Obs & Mean & Std. Dev. & Min & Max \\
\hline Gender parity & 510 & 0.699 & 0.285 & 0.028 & 1.873 \\
\hline Bureaucratic quality & 510 & 1.431 & 0.873 & -1.125 & 4.132 \\
\hline GDP per capita $(\ln )$ & 493 & 7.386 & 0.837 & 4.603 & 9.447 \\
\hline Average aid over 5 years & 510 & 26.578 & 52.483 & 0 & 490.095 \\
\hline Urbanization & 493 & 0.341 & 0.171 & 0.032 & 0.783 \\
\hline Youth cohort size & 510 & 33.418 & 4.536 & 13.896 & 43.932 \\
\hline Armed conflict intensity $(\ln )$ & 510 & -4.189 & 5.559 & -6.908 & 11.002 \\
\hline Ethnic fractionalization & 478 & 0.520 & 0.283 & 0.005 & 0.925 \\
\hline Protestant or other majority religion & 510 & 0.457 & 0.499 & 0 & 1 \\
\hline Islam & 510 & 0.320 & 0.467 & 0 & 1 \\
\hline Democracy level & 426 & 0.352 & 0.331 & 0 & 0.980 \\
\hline Population & 510 & 58.868 & 188.646 & 0.121 & 1351.805 \\
\hline
\end{tabular}

quality and average income level are not associated with less gender inequality. International education aid, reflecting western donor countries' priorities, appears to reduce gender inequality. Higher levels of urbanization is associated with less gender inequality, yielding some support for the capacity narrative, yet urban populations are generally also more receptive to modern views on female education, suggesting that willingness may also be at play. Interestingly, the measure of large youth cohorts is associated with lower levels of education inequality. Willingness factors provide the greatest explanatory power in the gender inequality models. There is less gender parity in ethnically fractionalized countries, and in countries where Islam is the greatest religion, everything else being equal.

The overarching policy implication from our study is that both the international community and national authorities need to actively work to remove social barriers to female education. Our results clearly indicate that the existence of large youth populations, which demands investments in the education system, does not have to be a barrier to expanding the relative access of education for girls and further that the extensive aid that has been provided to increasing education is indeed succeeding in reducing gender inequalities.

These cross-national aggregate models fail to identify the specific initiatives and projects that bring girls to school and allow them to stay there. One concrete simple, cost-effective way of getting more girls to attend school, which relates to both capacity and willingness factors, could be to help them manage menstruation. Aid workers are experimenting with giving teenage girls sanitary pads, along with access to toilets where they can change them. Initial findings are that this simple approach is effective in increasing female attendance at secondary schools (see, e.g., [75]: 172). Another broader effort is to enhance the quality of schools. As discussed above, we know that the quality of education and of educational facilities affects girls more than boys. Girls are less likely to enroll in, and more likely to drop out of, poor quality schools and schools that are lacking teachers and adequate school materials such as textbooks [16, 17].

Furthermore, it is important to stress that in addition to understanding what affects gender inequalities in education

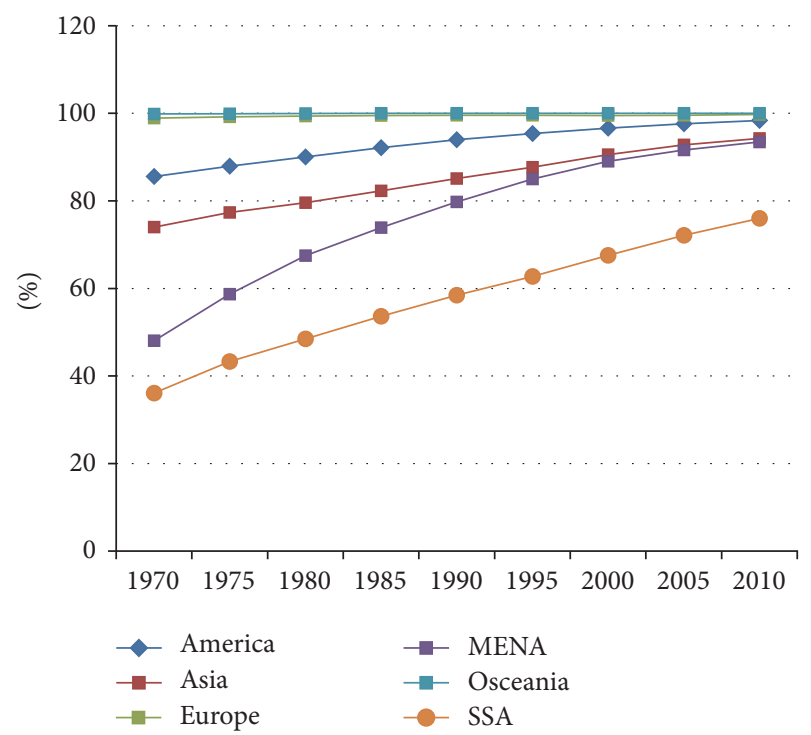

Figure 5: Share of females (15-24) with at least some primary education (lower secondary education and above), by region.

attainment we need to better understand the causes of gender gaps in terms of student performance. Such studies exist for, for example, OECD countries (e.g., [76]), but to our knowledge no such studies exist for developing countries. Finally, many of the factors that were found to be significant drivers of gender inequality in secondary education over time are also likely to impact the development of gender inequality in tertiary education, which is much more pronounced. (In Sub-Saharan Africa the gender parity in terms of tertiary education enrollment was below $20 \%$ in in all countries with existing data for 2012 [77].) These are challenges that will become more pressing as the access to tertiary education is further expanded, and they call for future research of barriers and opportunities.

\section{Appendix}

See Tables 6, 1, 7, 5, 2, and 3 and Figures 2, 3, and 5. 
TABLE 7: Gender parity in secondary education attainment, developing countries: 1970-2010. Lagged dependent variable included.

\begin{tabular}{|c|c|c|c|}
\hline & OLS & Random effects & Fixed effects \\
\hline \multirow{2}{*}{ Bureaucratic quality } & 0.0075 & 0.0068 & -0.0042 \\
\hline & $(0.0087)$ & $(0.0087)$ & $(0.0077)$ \\
\hline \multirow{2}{*}{ GDP per capita $(\ln )$} & 0.025 & 0.026 & -0.027 \\
\hline & $(0.022)$ & $(0.023)$ & $(0.048)$ \\
\hline \multirow{2}{*}{ Average aid over 5 years } & 0.00028 & 0.00028 & 0.00048 \\
\hline & $(0.00011)^{* *}$ & $(0.00012)^{* *}$ & $(0.00020)^{* *}$ \\
\hline \multirow{2}{*}{ Urbanization } & 0.159 & 0.185 & 1.064 \\
\hline & $(0.163)$ & $(0.176)$ & $(0.358)^{* * *}$ \\
\hline \multirow{2}{*}{ Youth cohort size } & 0.0068 & 0.0069 & 0.0081 \\
\hline & $(0.0032)^{* *}$ & $(0.0032)^{* *}$ & $(0.0052)$ \\
\hline \multirow{2}{*}{ Armed conflict intensity $(\ln )$} & -0.0010 & -0.0010 & 0.00032 \\
\hline & $(0.0013)$ & $(0.0013)$ & $(0.0014)$ \\
\hline \multirow{2}{*}{ Ethnic fractionalization } & -0.110 & -0.118 & \\
\hline & $(0.064)^{*}$ & $(0.068)^{*}$ & \\
\hline \multicolumn{4}{|c|}{ Largest religion (ref. cat: Catholicism) } \\
\hline \multirow{2}{*}{ Protestantism or other } & -0.0093 & -0.012 & \\
\hline & $(0.027)$ & $(0.028)$ & \\
\hline \multirow{2}{*}{ Islam } & -0.056 & -0.062 & \\
\hline & $(0.029)^{*}$ & $(0.031)^{* *}$ & \\
\hline \multirow{2}{*}{ Democracy level } & 0.010 & 0.012 & -0.012 \\
\hline & $(0.024)$ & $(0.025)$ & $(0.034)$ \\
\hline \multirow{2}{*}{ Gender parity } & 0.617 & 0.585 & -0.029 \\
\hline & $(0.166)^{* * *}$ & $(0.178)^{* * *}$ & $(0.246)$ \\
\hline \multirow{2}{*}{ Population } & 0.000020 & 0.000022 & 0.00023 \\
\hline & $(0.000029)$ & $(0.000030)$ & $(0.00018)$ \\
\hline \multirow{2}{*}{1975} & -0.024 & -0.026 & -0.035 \\
\hline & $(0.018)$ & $(0.017)$ & $(0.019)^{*}$ \\
\hline \multirow{2}{*}{1980} & -0.040 & -0.040 & -0.032 \\
\hline & $(0.031)$ & $(0.031)$ & $(0.016)^{* *}$ \\
\hline \multirow{2}{*}{1985} & -0.024 & -0.023 & -0.017 \\
\hline & $(0.030)$ & $(0.029)$ & $(0.014)$ \\
\hline \multirow{2}{*}{1990} & 0.010 & 0.011 & 0.018 \\
\hline & $(0.012)$ & $(0.012)$ & $(0.0091)^{*}$ \\
\hline \multirow{2}{*}{1995} & 0.013 & 0.014 & 0.034 \\
\hline & $(0.0090)$ & $(0.0089)$ & $(0.0081)^{* * *}$ \\
\hline \multirow{2}{*}{ Constant } & -0.066 & -0.051 & 0.319 \\
\hline & $(0.171)$ & $(0.174)$ & $(0.371)$ \\
\hline$R^{2}$ & 0.75 & & 0.46 \\
\hline$N$ & 361 & 361 & 361 \\
\hline
\end{tabular}

\section{Disclosure}

Replication data are available at http://www.prio.no/Data/.

\section{Competing Interests}

The authors declare that they have no competing interests.

\section{Acknowledgments}

This work was supported by the Research Council of Norway under Grant 230861/F10 and the Norwegian Ministry of Foreign Affairs. The authors would like to thank Bernd Beber, Erika Forsberg, Ismene Gizelis, Joshua Goldstein, Sabrina Karim, Zoe Marks, Ragnhild Nordås, Louise 
Olsson, and Håvard Strand for helpful comments and ideas on earlier versions. Replication data are available at http://www.prio.no/Data/.

\section{References}

[1] World Bank, World Development Report 2012: Gender Equality and Development, World Bank, Washington, DC, USA, 2012.

[2] A. Cooray and N. Potrafke, "Gender inequality in education: political institutions or culture and religion?" European Journal of Political Economy, vol. 27, no. 2, pp. 268-280, 2011.

[3] D. Dollar and R. Gatti, "Gender inequality, income, and growth: are good times good for women? Policy research report on gender and development," Working Paper Series 1, The World Bank, Washington, DC, USA, 1999.

[4] P. Glewwe and K. Michael, "Schools, teachers and education outcomes in developing countries," in Handbook of the Economics of Education, E. Hanushek and F. Welch, Eds., vol. 2, pp. 945-1012, Elsevier, Amsterdam, The Netherlands, 2006.

[5] C. Buchmann, T. A. DiPrete, and A. McDaniel, "Gender inequalities in education," Annual Review of Sociology, vol. 34, pp. 319-337, 2008.

[6] ECF (Education for Change), "Thematic study on education and gender equality," Report to Norwegian Agency for Development Cooperation, 2013.

[7] M. Tembon and L. Fort, Girls' Education in the 21st Century: Gender Equality, Empowerment, and Economic Growth, The International Bank for Reconstruction and Development and the World Bank, Washington, DC, USA, 2008.

[8] T. R. Müller, "Education for social change: girls' secondary schooling in Eritrea," Development and Change, vol. 37, no. 2, pp. 353-373, 2006.

[9] C. Hackett, B. J. Grim, M. Stonawski, V. Skirbekk, M. Potančoková, and G. Abel, The Global Religious Landscape: A Report on the Size and Distribution of the World's Major Religious Groups as of 2010, Pew Research Center, Washington, DC, USA, 2012, https://www.pewforum.org/files/2014/01/global-religionfull.pdf.

[10] B. Branisa, S. Klasen, and M. Ziegler, "Why we should all care about social institutions related to gender inequality," in Proceedings of the German Development Economics Conference, vol. 50, Hannover, Germany, 2010, http://hdl.handle.net/10419/ 39965.

[11] D. H. C. Chen, "Gender equality and economic development: the role for information and communication technologies," World Bank Policy Research Working Paper 3285, World Bank, Washington, DC, USA, 2004.

[12] C. Buchmann and E. Hannum, "Education and stratification in developing countries: a review of theories and research," Annual Review of Sociology, vol. 27, pp. 77-102, 2001.

[13] M. Warrington and S. Kiragu, "It makes more sense to educate a boy': girls 'against the odds' in Kajiado, Kenya," International Journal of Educational Development, vol. 32, no. 2, pp. 301-309, 2012.

[14] E. King and D. van der Walle, "Girls in hill tribes, Lao PDR: poverty and isolated communities," in Exclusion, Gender and Schooling: Case Studies from the Developing World, M. Lewis and M. Lockheed, Eds., Center for Global Development, Washington, DC, USA, 2007.

[15] C. B. Lloyd, S. El Tawila, W. H. Clark, and B. S. Mensch, "The impact of educational quality on school exit in Egypt," Comparative Education Review, vol. 47, no. 4, pp. 444-467, 2003.
[16] M. E. Lockheed, "The double disadvantage of gender and social exclusion in education," in Girls' Education in the 21st Century: Gender Equality, Empowerment, and Economic Growth, M. Tembon and L. Fort, Eds., The International Bank for Reconstruction and Development and the World Bank, Washington, DC, USA, 2008.

[17] Southern and Eastern Africa Consortium for Monitoring Educational Quality (SACMEQ), "Progress in gender equality in education: Kenya," Policy Brief Number 6, 2011.

[18] A. Sen and W. Easterly, "The man without a plan: can foreign aid work?” Foreign Affairs, vol. 85, no. 2, pp. 171-177, 2006.

[19] F. Trap, "Foreign aid," in The New Palgrave Dictionary of Economics, L. Blume and S. Durlauf, Eds., vol. 2, Palgrave Macmillan, Houndmills, UK, 2006.

[20] W. R. Easterly, The White Man's Burden: Why the West's Efforts to Aid the Rest Have Done So Much Ill and So Little Good, Penguin Press, New York, NY, USA, 2006.

[21] H. Doucouliagos and M. Paldam, "The aid effectiveness literature: the sad results of 40 years of research," Department of Economics Working Paper 2005.05, University of Aarhus, Aarhus, Denmark, 2005.

[22] M. McGillivray, S. Feeny, N. Hermes, and R. Lensink, "It works; it doesn't; it can, but that depends. 50 years of controversy over the macroeconomic impact of development aid," Research Paper 2005/54, United Nations University WIDER, Helsinki, Finland, 2005.

[23] S. Wolf, "Does aid improve public service delivery?" Review of World Economics, vol. 143, no. 4, pp. 650-672, 2007.

[24] P. Bennell, "Hitting the target: doubling primary school enrollments in sub-Saharan Africa by 2015," World Development, vol. 30, no. 7, pp. 1179-1194, 2002.

[25] E. Ransom and C. Bain, "Gendering agricultural aid: an analysis of whether international development assistance targets women and gender," Gender and Society, vol. 25, no. 1, pp. 48-74, 2011.

[26] K. Michaelowa and A. Weber, "Aid Effectiveness in the education sector: a dynamic panel analysis," in Theory and Practice of Foreign Aid: Frontiers of Economics and Globalization, S. Lahiri, Ed., vol. 1, Emerald Group Publishing Limited, Bingley, UK, 2006.

[27] S. Rahman, "Development, democracy and the NGO sector: theory and evidence from Bangladesh," Journal of Developing Societies, vol. 22, no. 4, pp. 451-473, 2006.

[28] United Nations (UN), World Population Prospects: The 2006 Revision, United Nations Population Division, New York, NY, USA, 2007.

[29] B. Jo, B. Guha-Khasnobis, and R. Kanbur, Urbanization and Development: Multidisciplinary Perspectives, Oxford University Press, Oxford, UK, 2010.

[30] J. Zhang, X. Pang, L. Zhang, A. Medina, and S. Rozelle, "Gender inequality in education in China: a meta-regression analysis," Working Paper 239, Rural Education Action Program (REAP), Stanford University, 2012.

[31] S. W. Norton and A. Tomal, "Religion and female educational attainment," Journal of Money, Credit and Banking, vol. 41, no. 5, pp. 961-986, 2009.

[32] C. Beer, "Democracy and gender inequality," in Studies in Comparative International Development, vol. 44, no. 3, pp. 212227, Springer, Berlin, Germany.

[33] H. Urdal, "A clash of generations? Youth bulges and political violence," International Studies Quarterly, vol. 50, no. 3, pp. 607629, 2006. 
[34] M. Buvinic, M. Das Gupta, U. Casabonne, and P. Verwimp, "Violent conflict and gender inequality: an overview," The World Bank Research Observer, vol. 28, no. 1, pp. 110-138, 2013.

[35] D. K. Cohen, "Female combatants and the perpetration of violence: wartime rape in the Sierra Leone civil war," World Politics, vol. 65, no. 3, pp. 383-415, 2013.

[36] C. Valente, "What did the Maoists ever do for us? Education and marriage of women exposed to civil conflict in Nepal," Working Paper 5741, World Bank, Policy Research Department, Washington, DC, USA, 2011.

[37] B. Lai and C. Thyne, "The effect of civil war on education, 198097," Journal of Peace Research, vol. 44, no. 3, pp. 277-292, 2007.

[38] V. Diwakar, "The effect of armed conflict on education: evidence from Iraq," Journal of Development Studies, vol. 51, no. 12, pp. 1702-1718, 2015.

[39] A. L. Dabalen and S. Paul, "Estimating the effects of conflict on education in Côte d'Ivoire," Journal of Development Studies, vol. 50, no. 12, pp. 1631-1646, 2014.

[40] J. D. Angrist and A. D. Kugler, "Rural windfall or a new resource curse? Coca, income, and civil conflict in Colombia," The Review of Economics and Statistics, vol. 90, no. 2, pp. 191-215, 2008.

[41] C. Rodríguez and F. Sánchez, "Armed conflict exposure, human capital investments, and child labor: evidence from Colombia," Defence and Peace Economics, vol. 23, no. 2, pp. 161-184, 2012.

[42] Z. Elkins and J. Sides, "Can institutions build unity in multiethnic states?" American Political Science Review, vol. 101, no. 4, pp. 693-708, 2007.

[43] T. A. J. Houweling, A. E. Kunst, C. W. N. Looman, and L. P. Mackenbach, "Determinants of under-5 mortality among the poor and the rich: a cross-national analysis of 43 developing countries," International Journal of Epidemiology, vol. 34, no. 6, pp. 1257-1265, 2005.

[44] F. Stewart, Horizontal Inequalities and Conflict: Understanding Group Violence in Multiethnic Societies, Palgrave Macmillan, Basingstoke, UK, 2008.

[45] UNESCO, EFA Global Monitoring Report 2015: Education for all 2000-2015: Achievements and Challenges, UNESCO, Paris, France, 2015.

[46] M. Lewis and M. Lockheed, Inexcusable Absence: Why 60 million Girls Still Aren't in School and What to Do about It? Center for Global Development, Washington, DC, USA, 2006.

[47] M. Hajj and U. Panizza, "Religion and education gender gap: are Muslims different?" Economics of Education Review, vol. 28, no. 3, pp. 337-344, 2009.

[48] N. Forsythe, R. P. Korzeniewicz, and V. Durrant, "Gender inequalities and economic growth: a longitudinal evaluation," Economic Development and Cultural Change, vol. 48, no. 3, pp. 573-617, 2000.

[49] H. Hoodfar, "Women, religion and the 'Afghan education movement' in Iran," Journal of Development Studies, vol. 43, no. 2, pp. 265-293, 2007.

[50] F. Fukuyama, "Social capital, civil society and development," Third World Quarterly, vol. 22, no. 1, pp. 7-20, 2001.

[51] M. Moaddel, "Religion and women: islamic modernism versus fundamentalism," Journal for the Scientific Study of Religion, vol. 37, no. 1, pp. 108-130, 1998.

[52] S. Seguino, "Help or hindrance? Religion's impact on gender inequality in attitudes and outcomes," World Development, vol. 39, no. 8, pp. 1308-1321, 2011.
[53] E. Bjarnegård and E. Melander, "Disentangling gender, peace and democratization: the negative effects of militarized masculinity," Journal of Gender Studies, vol. 20, no. 2, pp. 139-154, 2011.

[54] S. Klasen and C. Wink, "'Missing women': revisiting the debate," Feminist Economics, vol. 9, no. 2-3, pp. 263-299, 2003.

[55] J. Gerring, S. C. Thacker, and C. Moreno, "Centripetal democratic governance: a theory and global inquiry," American Political Science Review, vol. 99, no. 4, pp. 567-581, 2005.

[56] B. Russett, Grasping the Democratic Peace: Principles for a PostCold War World, Princeton University Press, Princeton, NJ, USA, 1993.

[57] D. S. Brown and W. Hunter, "Democracy and human capital formation: education spending in Latin America, 1980 to 1997," Comparative Political Studies, vol. 37, no. 7, pp. 842-864, 2004.

[58] W. Lutz, A. Goujon, K. C. Samir, and W. Sanderson, Reconstruction of Population by Age, Sex and Level of Educational Attainment for 120 Countries 1970-2000, IIASA, Laxenburg, Austria, 2007.

[59] K. C. Samir, B. Barakat, A. Goujon, V. Skirbekk, W. Sanderson, and W. Lutz, "Projection of populations by level of educational attainment, age, and sex for 120 countries for 2005-2050," Demographic Research, vol. 22, pp. 383-472, 2010.

[60] R. E. Dahl, "Adolescent brain development: a period of vulnerabilities and opportunities. Keynote address," Annals of the New York Academy of Sciences, vol. 1021, pp. 1-22, 2004.

[61] S. T. Faber, H. P. Nielsen, and K. B. Bennike, Place, (In)Equality and Gender: A Mapping of Challenges and Best Practices in Relation to Gender, Education and Population Flows in Nordic Peripheral Areas, Nordic Council of Ministers, Copenhagen, Denmark, 2015.

[62] W. H. Greene, Econometric Analysis, Prentice-Hall, Upper Saddle River, NJ, USA, 5th edition, 2003.

[63] C. S. Hendrix, "Measuring state capacity: theoretical and empirical implications for the study of civil conflict," Journal of Peace Research, vol. 47, no. 3, pp. 273-285, 2010.

[64] World Bank, World Development Report 2010: Development and Climate Change, World Bank, Washington, DC, USA, 2010.

[65] ICRG, International Country Risk Guide Methodology, The PRS Group, East Syracuse, NY, USA, 2012, http://www.prsgroup .com/wp-content/uploads/2012/11/icrgmethodology.pdf.

[66] S. Gates, H. Hegre, H. M. Nygård, and H. Strand, "Development consequences of armed conflict," World Development, vol. 40, no. 9, pp. 1713-1722, 2012.

[67] A. Dreher, P. Nunnenkamp, and R. Thiele, "Does aid for education educate children? Evidence from panel data," World Bank Economic Review, vol. 22, no. 2, pp. 291-314, 2008.

[68] B. Lacina and N. P. Gleditsch, "Monitoring trends in global combat: a new dataset of battle deaths," European Journal of Population, vol. 21, no. 2-3, pp. 145-166, 2005.

[69] A. Wimmer, L.-E. Cederman, and B. Min, "Ethnic politics and armed conflict: a configurational analysis of a new global data set," American Sociological Review, vol. 74, no. 2, pp. 316-337, 2009.

[70] R. La Porta, F. Lopez-de-Silanes, A. Shleifer, and R. Vishny, "An application of the Kakutani-KY Fan theorem in the theory of ordinary differential equations," Bulletin de l'Académie Polonaise des Sciences, vol. 15, no. 1, pp. 222-279, 1999.

[71] S. Gates, H. Hegre, M. P. Jones, and H. Strand, "Institutional inconsistency and political instability: polity duration, 18002000," American Journal of Political Science, vol. 50, no. 4, pp. 893-908, 2006. 
[72] M. G. Marshall, "Polity IV Project: Political Regime Characteristics and Transitions, 1800-2013," http://www.systemicpeace .org/polity/polity4.htm.

[73] T. Vanhanen, "A new dataset for measuring democracy, 18101998," Journal of Peace Research, vol. 37, no. 2, pp. 251-265, 2000.

[74] J. R. Vreeland, "The effect of political regime on civil war: unpacking anocracy," Journal of Conflict Resolution, vol. 52, no. 3, pp. 401-425, 2008.

[75] N. D. Kristof and S. WuDunn, Half the Sky: Turning Oppression into Opportunity for Women Worldwide, Knopf, New York, NY, USA, 2009.

[76] G. N. Marks, "Accounting for the gender gaps in student performance in reading and mathematics: evidence from 31 countries," Oxford Review of Education, vol. 34, no. 1, pp. 89-109, 2008.

[77] UNESCO, World Atlas of Gender Equality in Education, UNESCO, Paris, France, 2012, http://www.unesco.org/new/fileadmin/MULTIMEDIA/HQ/ED/pdf/Atlas-education-genderequalityl.pdf. 


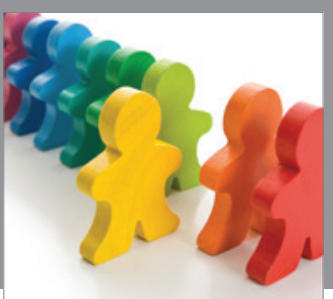

Autism

Research and Treatment
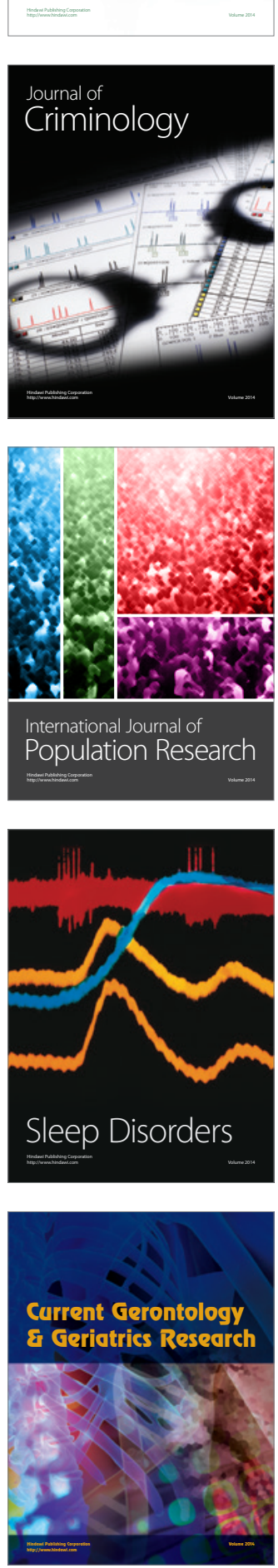

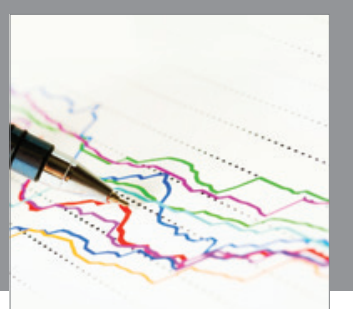

Economics

Research International
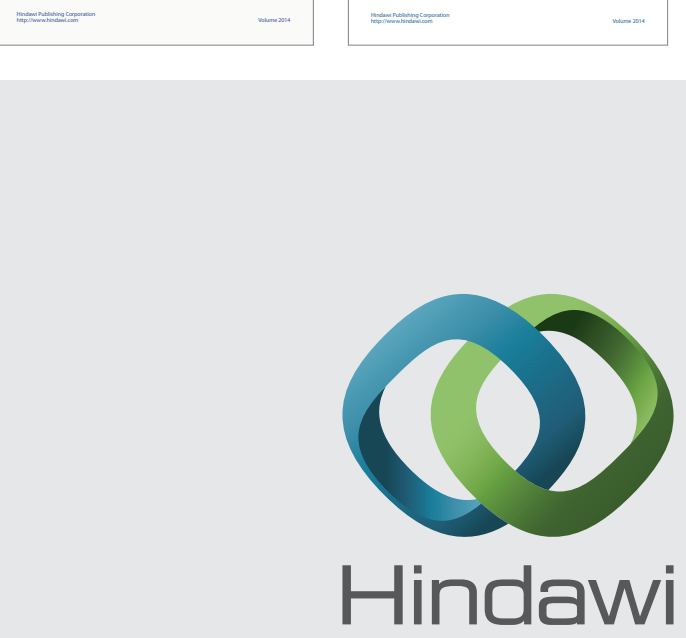

Submit your manuscripts at

http://www.hindawi.com
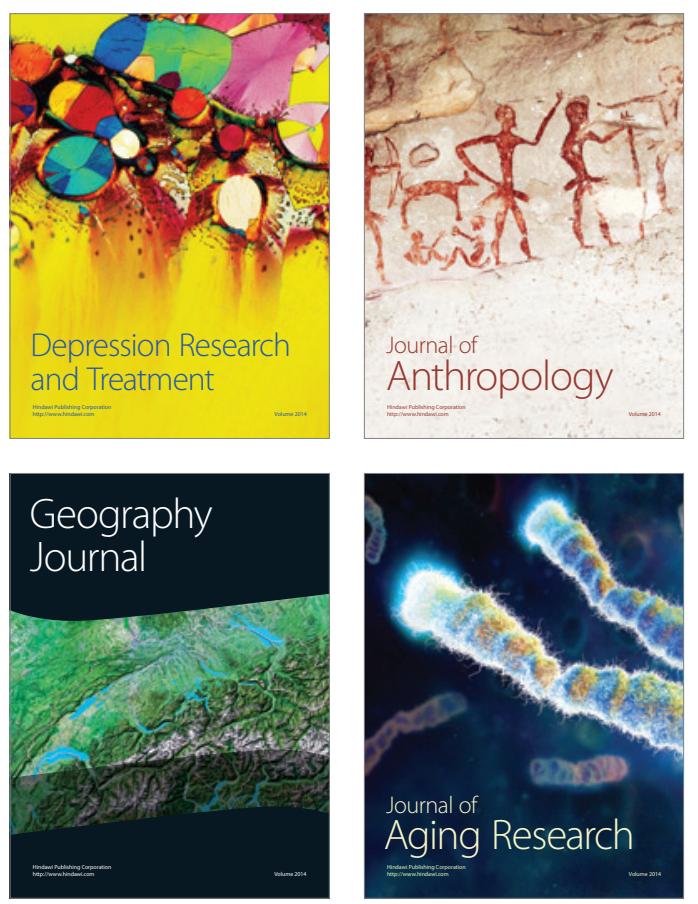
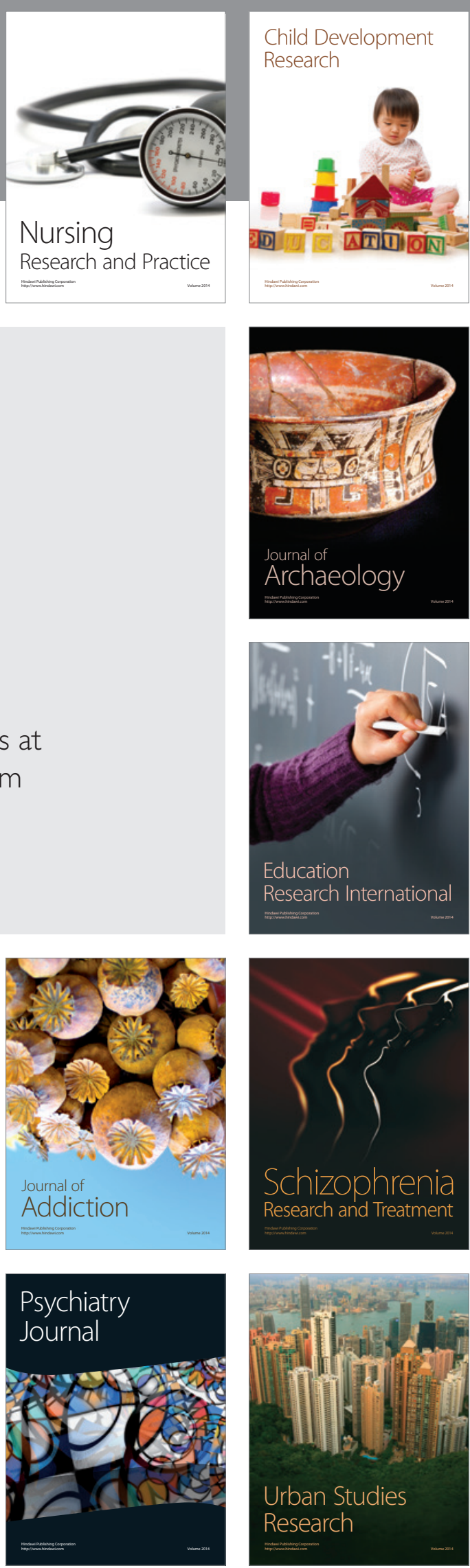